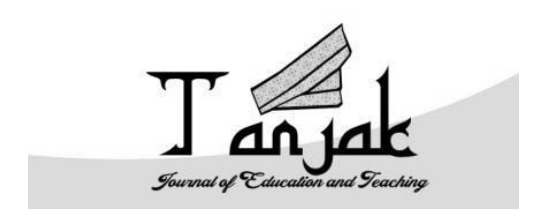

Tanjak: Journal of Education and Teaching

ISSN 2716-4098 (P) 2720-8966 (O)

Volume 2 Nomor 1, 2021

\title{
PENINGKATAN KEMAMPUAN GURU DALAM MENYUSUN RPP KURIKULUM 2013 MELALUI SUPERVISI AKADEMIK DI SMP NEGERI TANJUNGPINANG TAHUN 2018
}

\author{
Hariyana Safitri \\ SMP Negeri 2 Tanjungpinang, safitrihariyana@gmail.com
}

DOI: https://doi.org/10.35961/tanjak.v2i1.163

\begin{abstract}
Abstrak
Penelitian ini bertujuan Untuk mengetahui peningkatan kemampuan guru dalam menyusun RPP Kurikulum 2013 melalui supervisi akademik di SMP Negeri 2 Tanjungpinang Tahun 2018. Supervisi akademik merupakan suatu model pembinaan yang dilakukan oleh kepala sekolah atau pengawas kepada guru untuk membantu memecahkan masalah yang berhubungan dengan kegiatan pembelajaran agar kualitas pembelajaran bisa diraih dengan optimal. Penelitian Tindakan Sekolah (PTS) termasuk jenis penelitian kuantitatif menggunakan Analisis Diskriptif Komparatif dengan membandingkan hasil kondisi awal dengan hasil siklus I teknik penataran tingkat lokal (In House Training) dan hasil siklus II dengan teknik percakapan pribadi. Penelitian ini dilakukan dalam dua siklus. Supervisi akademik secara kelompok (In House Training), dengan hasil penelitian siklus I RPP Kurikulum 2013 yang dibuat oleh guru-guru masih belum optimal maka perlu diadakan supervisi lanjutan pada siklus II, yaitu pelaksanaan tindakan supervisi secara individual (percakapan individu). Hasil rata-rata kemampuan guru menyusun RPP Kurikulum 2013 pada kondisi awal adalah 67,38 (kategori cukup). Hasil rata-rata kualitas RPP yang disusun oleh guru pada siklus I adalah 75,02 (kategori baik). Peningkatan hasil siklus I dibanding kondisi awal adalah 7,64. Sedangkan hasil rata-rata kualitas RPP Kurikulum 2013 yang disusun guru pada siklus II adalah 81,89 (kategori baik). Peningkatan hasil siklus II dibanding hasil siklus I adalah 6,37.
\end{abstract}

Kata Kunci : Supervisi, Kemampuan, Kurikulum 2013

\begin{abstract}
This study aims to determine the increase in the ability of teachers in preparing RPP Curriculum 2013 through academic supervision at SMP Negeri 2 Tanjungpinang in 2018. Academic supervision is a model of coaching carried out by principals or supervisors to teachers to help solve problems related to learning activities for quality. learning can be achieved optimally. School action research (PTS) is a type of quantitative research using Comparative Descriptive Analysis by comparing the results of the initial conditions with the results of the first cycle of local level upgrading techniques (In House Training) and the results of the second cycle with private conversation techniques. This research was conducted in two cycles. Academic supervision as a group (In House Training), with the results of the research cycle I RPP Curriculum 2013 made by teachers is still not optimal, it is necessary to carry out further supervision in cycle II, namely the implementation of supervision measures individually (individual conversation).
\end{abstract}

Tanjak: Jounal of Education and Teaching, Vol. 2, No. 1, 2021 
The average result of the teacher's ability to prepare RPP Curriculum 2013 in the initial conditions is 67.38 (sufficient category). The average result of the quality of the lesson plans compiled by the teacher in the first cycle was 75.02 (good category). The increase in the yield of cycle I compared to the initial conditions was 7.64. Meanwhile, the average quality of RPP Curriculum 2013 compiled by the teacher in cycle II was 81.89 (good category). The increase in the yield of cycle II compared to the result of cycle I was 6.37.

Keywords: Supervision, Ability, Curriculum 2013

\section{Latar Belakang Masalah}

Kurikulum 2013 sudah diberlakukan terbatas pada tahun pelajaran 2013/2014, diharapkan mampu membangun sumber daya manusia Indonesia yang lebih berkarakter. Undang-undang Republik Indonesia Nomor 20 Tahun 2003 tentang Sistem Pendidikan Nasional menyatakan bahwa pendidikan adalah usaha sadar dan terencana untuk mewujudkan suasana belajar dan proses pembelajaran agar peserta didik secara aktif mengembangkan potensi dirinya untuk memiliki kekuatan spiritual keagamaan, pengendalian diri, kepribadian, kecerdasan, akhlak mulia, serta keterampilan yang diperlukan dirinya, masyarakat, bangsa dan negara. Selanjutnya dalam rangka mencapai tujuan tersebut disusun standar pendidikan nasional, terdiri atas: standar kompetensi lulusan, standar isi, standar proses, standar sarana prasarana, standar pendidik dan tenaga kependidikan, standar pengelolaan, standar pembiayaan, dan standar penilaian.

Lampiran IV Peraturan Menteri Pendidikan dan Kebudayaan Nomor 81A Tahun 2013 tentang Implementasi Kurikulum Pedoman Umum Pembelajaran, menyebutkan bahwa Strategi pembelajaran sangat diperlukan dalam menunjang terwujudnya seluruh kompetensi yang dimuat dalam Kurikulum 2013. Kurikulum 2013 ini memberlakukan pendekatan scientic dan autentik. Pada pendekatan scientic, siswa didorong agar mampu lebih baik dalam melakukan observasi (pengamatan), bertanya, menalar, mencoba, dan mengkomunikasikan obyek pembelajaran dengan baik. Sedangkan pada pendekatan autentik, siswa dinilai berdasarkan 3 aspek, yaitu pengetahuan, ketrampilan, dan sikap.

Kenyataan di lapangan, pemahaman guru SMP Negeri 2 Tanjungpinang dalam penyusunan RPP masih jauh dari harapan sebagaimana yang telah digariskan pada Kurikulum 2013, di antaranya: (1) Tujuan pembelajaran belum disusun secara logis artinya belum disusun dari yang mudah ke yang sukar dan belum menunjukkan audience, behavior, condition dan degree; (2) pada alur rencana pelaksaanaan pembelajaran yang disusun belum menunjukkan tahapan kegiatan eksplorasi, elaborasi dan konfirmasi, sehingga RPP yang dibuat kurang bermakna; dan (3) Rencana penilaian autentik belum nampak, dan sebagainya. Dengan demikian, RPP kurikulum 2013 yang dibuat oleh guru kualitasnya masih rendah sehingga membutuhkan upaya-upaya peningkatan mutu dan butuh bimbingan, pemotivasian serta arahan dari kepala sekolah.

Tujuan yang hendak dicapai dalam penelitian ini adalah: (1) untuk mengetahui pelaksanaan supervisi akademik di SMP Negeri 2 Tanjungpinang Tahun 2018; (2) untuk mengetahui peningkatan kemampuan guru dalam menyusun RPP Kurikulum 2013 melalui supervisi akademik di SMP Negeri 2 Tanjungpinang Tahun 2018.

\section{Metode Penelitian}

Penelitian yang dilakukan termasuk penelitian tindakan sekolah. Oleh karena itu, rancangan yang khusus untuk sebuah penelitian tindakan sangat diperlukan. Penelitian tindakan didasarkan pada filosofi bahwa setiap manusia tidak suka atas hal-hal yang statis, tetapi selalu menginginkan sesuatu yang lebih baik. Peningkatan diri untuk hal yang lebih baik ini dilakukan terus menerus sampai tujuan tercapai (Suharsimi Arikunto, Suhardjono, Supardi, 2006: 6-7).

Rancangan tindakan dilakukan dengan prosedur penelitian berdasarkan pada prinsip Kemmis dan Taggart (1988) yang mencakup kegiatan sebagai berikut : (1) perencanaan (planning), (2) pelaksanaan tindakan (action), 3) observasi (observation), (4) refleksi (reflection) atau evaluasi. Keempat kegiatan ini berlangsung secara berulang dalam bentuk siklus.

Tanjak: Jounal of Education and Teaching, Vol. 2, No. 1, 2021 
Rancangan Penelitian Tindakan menurut (Arikunto, Suharsimi, 2007) adalah seperti gambar berikut :

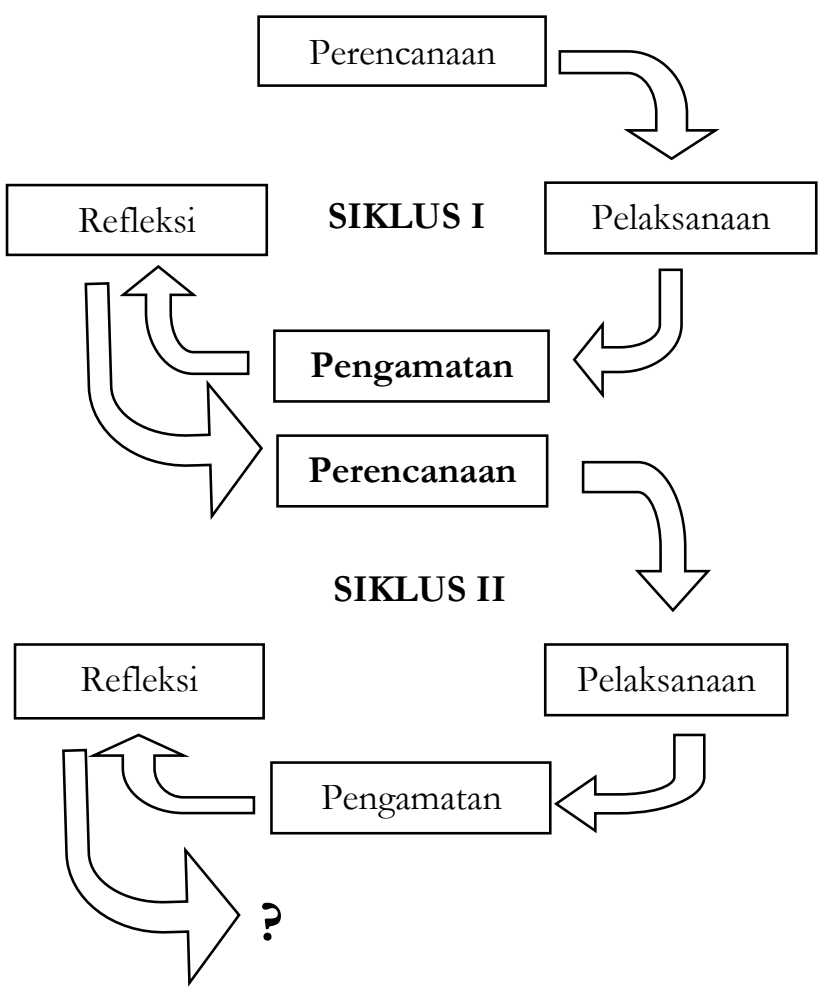

Gambar 1. Desain Penelitian Tindakan Sekolah

Sampel dalam penelitian tindakan sekolah ini berjumlah 12 orang dari 25 guru SMP Negeri 2 Tanjungpinang, tahun pelajaran 2018. Dalam penelitian ini teknik pengumpulan data yang penulis pergunakan adalah observasi dan alat pengumpulan data berupa instrument observasi dan instrument penyusunan RPP kurikulum 2013. Analisa data yang peneliti gunakan adalah analisis diskriptif komparatif menghitung peningkatannya dengan membandingkan kondisi awal, hasil siklus I ( supervisi akademik secara kelompok) dan hasil siklus II (supervisi akademik secara individu).

Penelitian ini dilakukan dengan menggunakan metode penelitian tindakan sekolah. Peneliti senantiasa berupaya memperoleh hasil yang optimal melalui cara dan prosedur yang dinilai paling efektif. Penelitian ini diharapkan dapat membantu guru menyusun RPP Kurikulum 2013. Peneliti melaksanakan penelitian dua siklus. Dimulai siklus I sejak: 1) perencanaan tindakan, 2) pelaksanaan tindakan, 3) Pengamatan, dan 4) Refleksi hingga siklus II .

\section{Siklus I}

a Perencanaan Tindakan (planning)

(1) Sebelum penelitian peneliti terjun ke lapangan untuk melihat kondisi awal RPP yang sudah dibuat guru yang mengajar di kelas VII, kelas VIII, dan Kelas IX

(2) Menyampaikan hasil kondisi awal dan menyampaikan rencana tindakan kepada guru dan kolaborator.

(3) Menyiapkan lembar/Instrumen penilaian RPP Kurikulum 2013

b. Pelaksanaan tindakan (action)

Peneliti melaksanakan tindakan supervisi akademik secara kelompok (in house training) mengenai RPP dan membuat RPP Kurikulum 2013 secara kelompok berdasarkan kelas.

c. Pengamatan (observation)

Peneliti dan kolaborator mengamati pelaksanaan tindakan dengan mengisi instrumen

Tanjak: Jounal of Education and Teaching, Vol. 2, No. 1, 2021 


\section{Siklus II}

observasi dan setelah pelaksanaan tindakan menilai RPP Kurikulum 2013 yang dibuat guru dengan menggunakan instrumen penyusunan RPP. Kemudian hasil pengamatan kolaborator diserahkan kepada peneliti.

d. Refleksi ( reflection)

Pada akhir siklus I ini diadakan refleksi berdasarkan data / hasil pengamatan kolaborator agar peneliti dapat melihat bahwa supervisi akademik yang dilakukan dalam penelitian ini dapat meningkatkan penyusunan RPP Kurikulum 2013 atau tidak.

a Perencanaan Tindakan (planning)

Peneliti menyampaikan hasil penyusunan RPP Kurikulum 2013 pada siklus I kepada kolaborator dan menginformasikan rencana pelaksanaan tindakan pada siklus II.

b. Pelaksanaan tindakan (action)

Peneliti memberikan supervisi akademik secara individu (percakapan individu)) serta mengamati RPP yang disusun oleh guru dengan harapan masing-masing guru mengetahui kelebihan dan kekurangannya tentang RPP Kurikulum 2013 yang sudah dibuat pada siklus I dengan harapan hasil pada siklus II akan meningkat.

c. Pengamatan (observation)

Peneliti dan kolaborator melaksanakan pengamatan dengan mengisi lembar observasi dan menilai RPP Kurikulum 2013 menggunakan instrumen penyusunan RPP setelah pelaksanaan tindakan (seperti pada siklus I)

d. Refleksi (reflection)

Pada akhir tiap siklus diadakan refleksi berdasarkan data observasi agar peneliti dapat melihat apakah tindakan yang dilakukan dalam penelitian ini dapat meningkatkan kualitas RPP Kurikulum 201 atau tidak dibanding hasil siklus I.

Indikator keberhasilan guru dalam menyusun RPP Kurikulum 2013 berdasarkan pedoman Penilaian RPP Kurikulum 2013 adalah sebagai berikut: Apabila nilai kemampuan guru dalam menyusun RPP Kurikulum 2013 mengalami peningkatan dari observasi dengan observasi akhir atau minimal sebanyak $90 \%$ dari 12 guru yang menjadi subyek penelitian mendapat nilai $\geq 75$, berarti pelaksanaan supervisi akademik telah berhasil meningkatkan kemampuan guru SMP guru SMP Negeri Tan2 jungpinang tahun 2018 dalam menyusun RPP Kurikulum 2013.

\section{Hasil Penelitian dan Pembahasan}

\section{A. Hasil Penelitian}

\section{Deskripsi Kondisi Awal}

Kondisi Awal RPP yang dibuat guru SMP Negeri 2 Tanjungpinang menunjukkan bahwa rata-rata kualitas RPP yang dibuat guru dengan rata-rata 67,38 (cukup) dimana hanya $2(16,67 \%$ ) orang guru yang mencapai nilai $\geq 75$ (Baik), maka perlu disupervisi akademik secara kelompok (in house training) agar hasilnya bisa meningkat.

a. Siklus I

Tindakan peneliti diawali dengan pertemuan dengan WKs Kurikulum pada saat IHT Bersama SMP Negeri 2 Tanjungpinang, penulis menyampaikan instrumen hasil penilaian RPP kondisi awal dan membicarakan rencana penelitian peningkatan kualitas RPP kurikulum 2013. Penulis menginformasikan kepada WKS Kurikulum, serta para guru SMP Negeri 2 Tanjungpinang terlibat dalam penelitian ini sebagai kolaborator. Kemudian menjelaskan isi dan cara pengisian instrumen tersebut.

Pelaksanaan tindakan dalam tahap siklus I ini peneliti mengadakan supervisi akademik secara kelompok (in house training). Peserta terdiri dari 12 orang guru SMP Negeri 2 Tanjungpinang dan

Tanjak: Jounal of Education and Teaching, Vol. 2, No. 1, 2021 
diobservasi oleh peneliti.

Setelah selesai workshop tingkat lokal (IHT) masing-masing guru membuat RPP Kurikulum 2013. Kemudian RPP yang dibuat guru tersebut diserahkan kepada kolaborator yaitu WKS Kurikulum untuk dinilai menggunakan instrumen dan juknisnya yang telah disediakan peneliti. Setelah RPP yang dibuat oleh guru dinilai oleh kolabrator yaitu WKS Kurikulum dengan instrumen yang sudah disediakan peneliti, hasilnya diserahkan kepada kepala sekolah (peneliti).

\section{b. Refleksi}

Peneliti melakukan refleksi setelah melaksanakan tindakan siklus I, yaitu dengan melaporkan hasil evaluasi setelah Siklus I berdasarkan analisis kemempuan guru dalam menyusun RPP. Evaluasi peningkatan kemampuan guru dalam menyusun RPP kurikulum 2013 dilakukan melalui supervisi akademik. Hasil tindakan supervisi akademik yang didasarkan pada pengamatan terhadap 12 orang guru di SMP Negeri 2 Tanjungpinang Tahun 2018 dengan melakukan analisis yaitu:

\section{(1) Analisis Perorangan}

Berdasarkan tabel di atas, dapat diperoleh data bahwa terjadi kenaikan perolehan skor pada tiap guru. Pada siklus I ini ,hasil observasi peneliti diperoleh data bahwa 8 (66,67\%) orang guru memperoleh perolehan skor $\geq 75$ (Baik), sedangkan guru yang hanya memperoleh skor 61 s.d 7 (Cukup) berjumlah $4(33,33 \%)$ orang dan tidak ada lagi guru yang memperoleh skor kecil dari 60 (Kurang). Hasil pengamatan Siklus menunjukan bahwa terjadi peningkatan kemampuan guru dalam RPP kurikulum 2013. Untuk jelasnya dapat dilihat pada tabel di bawah ini :

Tabel 1. Hasil Analisis Guru dalam Menyusun RPP Kurikulum 2013 (Siklus I)

\begin{tabular}{|c|c|c|c|}
\hline Rentang Nilai & Jumlah & Persentase & Katagori \\
\hline 85 s.d. 100 & - & - & Sangat Baik \\
\hline 75 s.d 84 & 8 & $66,67 \%$ & Baik \\
\hline 60 s.d 74 & 4 & $33,33 \%$ & Cukup \\
\hline$<60$ & - & - & Kurang \\
\hline
\end{tabular}

(2) Peningkatan Per Aspek Pengamatan

Hasil Peningkatan per aspek pengamatan Rencana Pelaksanaan Pembelajaran ( RPP) Kurikulum 2013 yang terdiri dari 7 aspek pada Siklus I dapat dilihat pada tabel sebagai berikut :

Tabel 2. Peningkatan Kemampuan Guru Menyusun RPP Kurikulum 2013 (Siklus I )

\begin{tabular}{|c|c|c|c|}
\hline Aspek Yang di Nilai & Prasiklus & Siklus I & Peningkatan \\
\hline Perumusan Indikator & 65,50 & 73,75 & 8,25 \\
\hline Perumusan Tujuan Pembelajaran & 68,75 & 75,17 & 6,42 \\
\hline Materi Pembelajaran & 67,83 & 75,67 & 7,83 \\
\hline Media Pembelajaran & 68,50 & 74,17 & 5,67 \\
\hline Metode Pembelajaran & 65,33 & 74,42 & 9,08 \\
\hline Rencana Kegiatan Pembelajaran & 67,33 & 76,33 & 8,00 \\
\hline Penilaian & 68,42 & 76,67 & 8,25 \\
\hline
\end{tabular}

Berdasarkan tabel di atas, dapat diperoleh data yaitu sebagai berikut :

(a) Aspek Perumusan Indikator yang terdiri dari 5 Indikator, pada Prasiklus perolehan skornya 65,50, setelah melalui Siklus I naik 8,25 sehingga menjadi 73,75.

(b) Aspek Perumusan Tujuan Pembelajaran yang terdiri dari 4 Indikator, pada Prasiklus perolehan skornya 68,75 setelah melalui Siklus I naik 6,42 sehingga menjadi 75,17.

(c) Aspek Materi Pembelajaran yang terdiri dari 7 Indikator, pada Prasiklus perolehan

Tanjak: Jounal of Education and Teaching, Vol. 2, No. 1, 2021 
skornya 67,83 setelah melalui Siklus I naik 7,83 sehingga menjadi 75,67.

(d) Aspek Media Pembelajaran yang terdiri dari 4 Indikator, pada Prasiklus perolehan skornya 68,50 setelah melalui Siklus I naik 5,67 sehingga menjadi 74,17.

(e) Aspek Metode Pembelajaran yang terdiri dari 4 Indikator, pada Prasiklus perolehan skornya 65,33 setelah melalui Siklus I naik 9,08 sehingga menjadi 74,72.

(f) Aspek Rencana Kegiatan Pembelajaran yang terdiri dari 9 Indikator, pada Prasiklus perolehan skornya 67,33 setelah melalui Siklus I naik 8,00 sehingga menjadi 73,33.

(g) Aspek Penilaian yang terdiri dari 6 Indikator, pada Prasiklus perolehan skornya 68,42 setelah melalui Siklus I naik 8,25 sehingga menjadi 76,67.

\section{(3) Analisis keseluruhan}

Secara keseluruhan, kemampuan guru dalam menyusun RPP kurikulum 2013 meningkat setelah melalui supervisi akademik pada siklus 1. hal ini terlihat dari Rata-rata skor dari 12 guru pada prasiklus yang hanya mencapai 67,78 dengan predikat Cukup, naik 7,64 menjadi 72,02 dengan kriteria Baik. Dengan adanya peningkatan rata-rata skor secara keseluruhan ini, maka dapat dikatakan bahwa supervisi akademik yang dilaksanakan dapat meningkatkan kemampuan guru dalam menyusun RPP namun belum mencapai target yang telah ditetapkan karena kemapuan guru dalam menyusun RPP dengan baik belum mencapai 90\% sehingga perlu tindakan lanjutan yaitu supervisi akademik pada siklus II.

\section{Deskripsi Siklus II}

\section{a. Perencanaan Tindakan}

Menyampaikan hasil siklus I kepada guru dan kolaborator. Kekurangan hasil pada siklus I ini ditindaklanjuti peneliti dengan merencanakan supervisi akademik secara individual (percakapan pribadi) untuk membina secara individu membahas RPP hasil supervisi akademik dipadukan dengan juknis yang ada agar guru mengetahui kekurangsempurnaan RPP yang sudah dibuat serta Peneliti membantu menyempurnakan dan memecahkan kesulitan guru.

\section{b. Pelaksanaan Tindakan}

Pelaksanaan supervisi akademik siklus II ini dilaksanakan secara individual (percakapan pribadi dan pengamatan) oleh peneliti dan kolaborator (WKS Kurikulum) untuk membantu guru menyempurnakan RPP yang dibuat guru pada siklus I dipadukan dengan juknis yang ada, guru diberi kesempatan untuk menanyakan sampai sejelas-jelasnya dengan harapan RPP yang akan dibuat dalam siklus II nanti hasilnya lebih optimal. Dalam siklus II ini setelah diadakan supervisi akademik secara individu, para guru membuat RPP. RPP yang dibuat guru diserahkan kepada kolaborator. Hasil RPP yang dibuat guru dan instrumen yang sudah diisi diserahkan kepada peneliti.

\section{c. Hasil Pengamatan}

RPP Kurikulum 2013 yang dibuat guru-guru setelah mendapat supervisi akademik secara individual hasilnya meningkat. RPP Kurikulum 2013 yang dibuat guru pada siklus II ini sudah menunjukkan peningkatan-peningkatan dibanding siklus I. Sebagian besar rumusan tujuan pembelajaran lebih lengkap dan lebih jelas, materi ajar sudah dijabarkan dan sudah melatih ingatan, pemahaman dan penerapan, Kegiatan inti sudah menunjukkan aktivitas m e n g a m a t i, me n a n y a, Mengeksplorasi, Mengasosiasi dan Mengomunikasikan. Pada Kegiatan akhir pertanyaan sudah meliputi ingatan, pemahaman penerapan. Tabel di atas menunjukkan bahwa supervisi akademik secara individual dapat lebih meningkatkan kemampuan guru dalam menyusun RPP Kurikulum 2013.

\section{d. Refleksi}

Peneliti melakukan refleksi setelah melaksanakan tindakan siklus II, yaitu dengan melaporkan hasil evaluasi setelah Siklus II berdasarkan analisis kemempuan guru dalam menyusun RPP. Evaluasi peningkatan kemampuan guru dalam menyusun RPP Kurikulum 2013 dilakukan melalui supervisi akademik pendidikan. Hasil tindakan supervisi yang didasarkan pada pengamatan terhadap 12 orang guru SMP Negeri 2 Tanjungpinang Tahun 2018 dengan melakukan analisis yaitu :

Tanjak: Jounal of Education and Teaching, Vol. 2, No. 1, 2021 


\section{(1) Analisis Perorangan}

Berdasarkan tabel di atas, dapat diperoleh data bahwa terjadi kenaikan perolehan skor pada tiap guru. Pada siklus II ini, hasil observasi peneliti diperoleh data bahwa 3 (25\%) orang guru memperoleh perolehan skor $\geq 85$ (Sangat Baik), guru yang memperoleh perolehan skor 75 s.d 84 (Baik) berjumlah $8(66,67 \%)$ orang, guru yang memperoleh nilai 61 s.d 74 ( cukup) hanya $1(8,33 \%)$. Hasil pengamatan Siklus II menunjukan bahwa terjadi peningkatan kemampuan guru dalam menyusun RPP Kurikulum 2013. 11 guru (91,67\%) telah mampu menyusun RPP Kurikulum 2013 dengan Baik dan berada pada Katagori Baik dengan hasil rata-rata skor dari 12 orang guru yaitu 81,39. Untuk jelasnya dapat dilihat pada tabel dan bawah ini:

Tabel 3. Hasil Analisis Guru dalam menyusun RPP Kurikulum 2013 (Siklus II)

\begin{tabular}{|c|c|c|c|}
\hline Rentang Nilai & Jumlah & Persentase & Katagori \\
\hline 85 s.d. 100 & 3 & $25 \%$ & Sangat Baik \\
\hline 75 s.d 84 & 8 & $66,67 \%$ & Baik \\
\hline 61 s.d 74 & 1 & $8,33 \%$ & Cukup \\
\hline$<61$ & - & $0 \%$ & Kurang \\
\hline
\end{tabular}

\section{(2) Peningkatan Per Aspek Pengamatan}

Hasil Peningkatan per aspek pengamatan yang terdiri dari 7 Indikator kemampuan guru dalam menyusuun RPP Kurikulum 2013 dapat dilihat pada tabel sebagai berikut:

Tabel 4. Peningkatan Kemampuan Guru dalam menyusun RPP Kurikulum 2013 (Siklus II)

\begin{tabular}{|l|c|c|c|}
\hline \multicolumn{1}{|c|}{ Aspek Yang di Nilai } & Siklus I & Siklus II & Peningkatan \\
\hline Perumusan Indikator & 73,75 & 80,58 & 6,83 \\
\hline Perumusan Tujuan Pembelajaran & 75,17 & 82,00 & 6,83 \\
\hline Materi Pembelajaran & 75,67 & 82,50 & 6,83 \\
\hline Media Pembelajaran & 74,17 & 81,00 & 6,83 \\
\hline Metode Pembelajaran & 74,42 & 79,50 & 5,08 \\
\hline Rencana Kegiatan Pembelajaran & 75,33 & 80,92 & 5,58 \\
\hline Penilaian & 76,67 & 83,25 & 6,58 \\
\hline
\end{tabular}

Berdasarkan tabel di atas, dapat diperoleh data yaitu sebagai berikut :

(a) Aspek Perumusan Indikator yang terdiri dari 5 Indikator, pada siklus I perolehan skornya 73,75, setelah melalui Siklus II naik 6, 83 sehingga menjadi 80,58.

(b) Aspek Perumusan Tujuan Pembelajaran yang terdiri dari 4 Indikator, pada Siklus I perolehan skornya 75,17 setelah melalui Siklus II naik 6,83 sehingga menjadi 82,00.

(c) Aspek Materi Pembelajaran yang terdiri dari 7 Indikator, pada Siklus I perolehan skornya 75,67 setelah melalui Siklus II naik 6,83 sehingga menjadi 82,50.

(d) Aspek Media Pembelajaran yang terdiri dari 4 Indikator, pada Siklus I perolehan skornya 74,17 setelah melalui Siklus II naik 5,08 sehingga menjadi 81,00.

(e) Aspek Metode Pembelajaran yang terdiri dari 4 Indikator, pada Siklus perolehan skornya 74,72 setelah melalui Siklus I naik 9,08 sehingga menjadi 79,50.

(f) Aspek Rencana Kegiatan Pembelajaran yang terdiri dari 9 Indikator, pada Siklus I perolehan skornya 73,33 setelah melalui Siklus II naik 5,58 sehingga menjadi 80,92.

(g) Aspek Penilaian yang terdiri dari 6 Indikator, pada Siklus I perolehan skornya 76,67 setelah melalui Siklus II naik 6,58 sehingga menjadi 83,25.

Berikut adalah grafik peningkatan per aspek kemampuan guru dalam menyusun RPP

Kurikulum 2013.

Tanjak: Jounal of Education and Teaching, Vol. 2, No. 1, 2021 


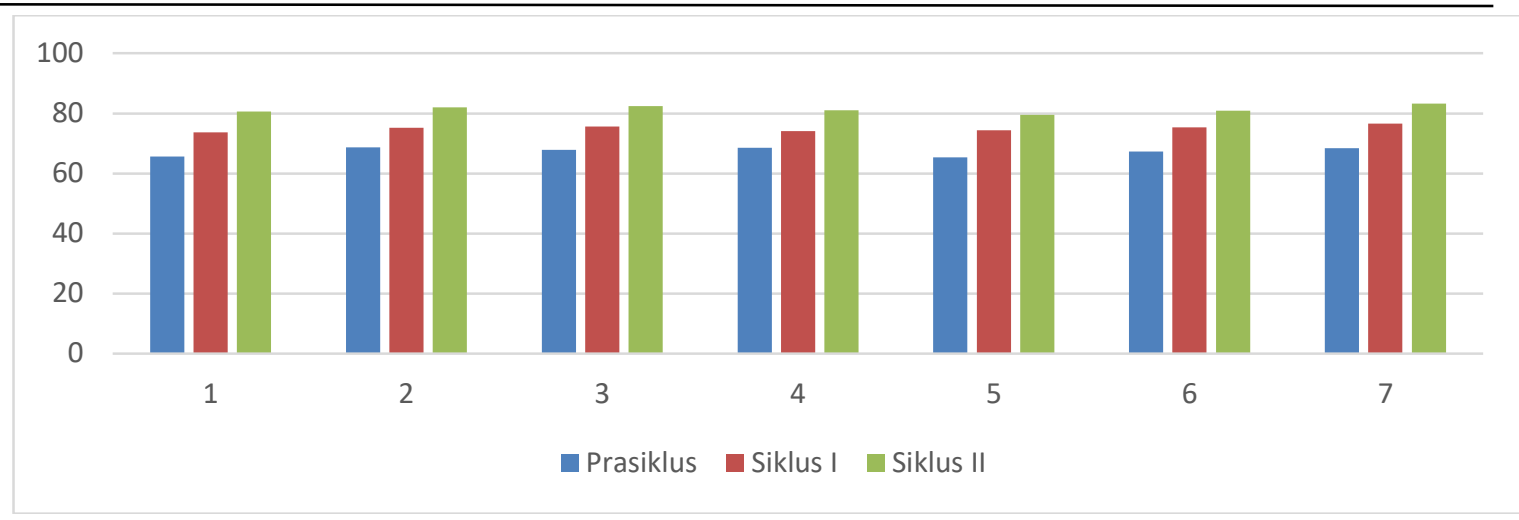

Gambar 2. Grafik Peningkatan PerAspek Kemampuan Guru dalam Menyusun RPP Kurikulum 2013

\section{Analisis keseluruhan}

Secara keseluruhan, kemampuan guru meningkat dalam menyusun RPP Kurikulum 2013 setelah melalui siklus II. Hal ini terlihat dari Rata-rata skor dari 12 guru pada Siklus I yang hanya mencapai 75,02 naik 6,37 menjadi 81,39 dengan kriteria Baik. Dengan adanya peningkatan rata- rata skor secara keseluruhan ini, maka dapat dikatakan bahwa supervisi akademik yang dilaksanakan dapat meningkatkan kemampuan guru dalam menyusun RPP Kurikulum 2013. Berikut adalah Grafik Peningkatan Kemampuan Guru dalam menyusun RPP Kurikulum 2013.

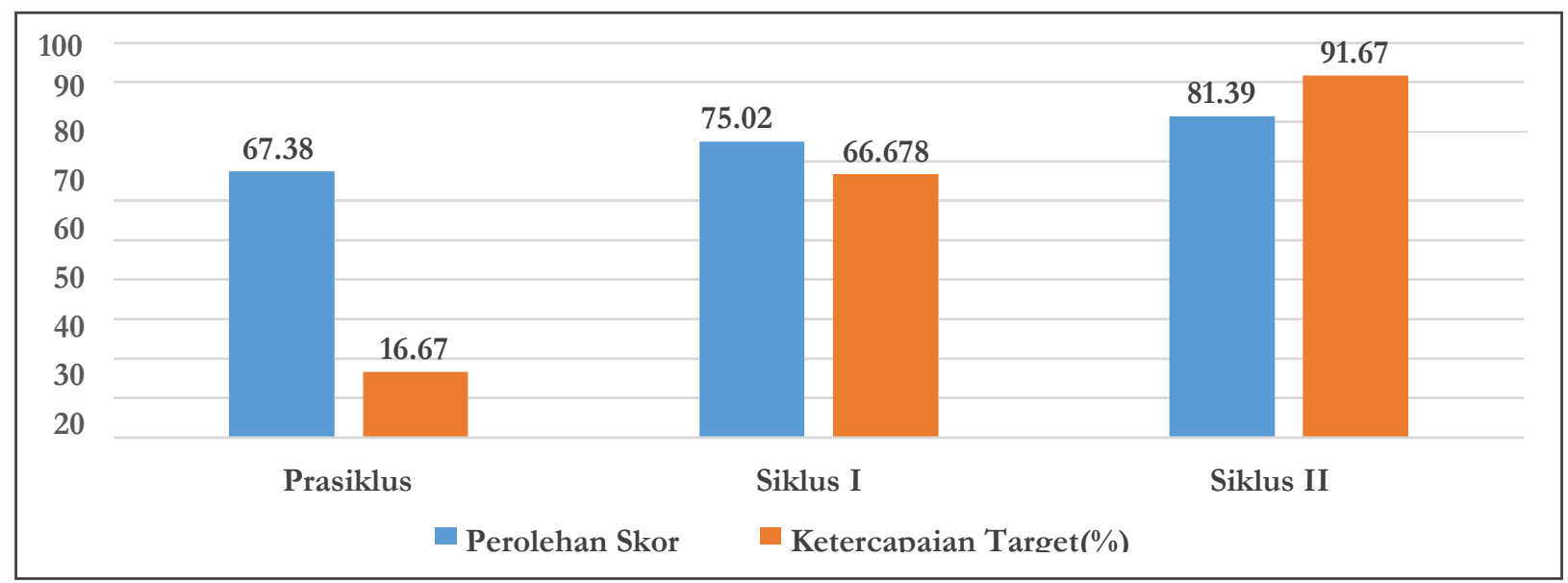

Gambar 2. Grafik Peningkatan Kemampuan Guru dalam menyusun RPP Kurikulum 2013

\section{B. Pembahasan}

\section{Siklus I}

Pelaksanaan siklus I dilaksanakan setelah melihat kondisi awal, kemudian dimulai dengan memberikan bimbingan secara kelompok (in house training) menyusun RPP Kurikulum 2013 untuk 1 minggu, hasilnya dinilai kolaborator yaitu WKS Kurikulum dengan menggunakan instrumen supervisi akademik dan juknis yang disiapkan peneliti. RPP Kurikulum 2013 tersebut kemudian diserahkan kepada peneliti beserta hasilnya. Hasil pada siklus I rata-rata skor yaitu 75,02 naik 7,64\% dibanding kondisi awal yang hanya 67,38, namun masih belum maksimal karena dari 12 guru hanya 8 (66,67\%) yang memperoleh skor $\geq 75$, maka perlu supervisi akademik secara individual (percakapan pribadi) pada tindakan siklus II.

\section{Siklus II}

Setelah mengetahui kekurangan RPP Kurikulum 2013 yang dibuat guru pada siklus I peneliti memberikan supervisi akademik secara individu (percakapan pribadi) tentang kekurang-sempurnaan RPP Kurikulum 2013 guru agar lebih baik pada siklus II, terbukti hasilnya meningkat 6,37\% dibanding hasil siklus I dan guru yang memperoleh skor $\geq 75$ mencapai 11 orang guru (91,67\%). Supervisi akademik secara

Tanjak: Jounal of Education and Teaching, Vol. 2, No. 1, 2021 
individu ternyata lebih efektif dibanding supervisi kelompok. Lebih jelasnya dapat diamati pada table di bawah ini.

Tabel 5. Hasil penelitian Kemampuan Guru dalam menyusun RPP Kurikulum 2013

\begin{tabular}{|c|l|c|c|c|}
\hline NO & \multicolumn{1}{|c|}{ KODE \& MAPEL GURU } & PRASIKLUS & SIKLUS I & SIKLUS II \\
\hline 1 & A D, Bahasa Indonesia & 55 & 70 & 79 \\
\hline 2 & N, Bahasa Inggris & 67 & 75 & 81 \\
\hline 3 & DD, IPA & 74 & 77 & 87 \\
\hline 4 & LP, Matematika & 75 & 78 & 87 \\
\hline 5 & S, PKn & 69 & 72 & 81 \\
\hline 6 & N, IPS & 72 & 73 & 77 \\
\hline 7 & SM, PAI & 76 & 83 & 91 \\
\hline 8 & S, PJOK & 72 & 75 & 81 \\
\hline 9 & NEA, Seni Budaya & 76 & 71 & 74 \\
\hline 10 & I, Prakarya & 55 & 76 & 80 \\
\hline 11 & PPR, IPA & 58 & 72 & 75 \\
\hline 12 & SH, Bahasa Indonesia & $\mathbf{6 7 , 3 8}$ & $\mathbf{7 5 , 0 2}$ & $\mathbf{8 1 , 3 9}$ \\
\hline & RATA-RATA SKOR & $\mathbf{1 6 , 6 7 \%}$ & $\mathbf{6 6 , 6 7 \%}$ & $\mathbf{9 1 , 6 7 \%}$ \\
\hline & KETERCAPAIAN TARGET $\geq \mathbf{7 5}$ & &
\end{tabular}

Hasil supervisi akademik yang dilaksanakan oleh peneliti yang berkolaborasi dengan WKS Kurikulum, kualitas RPP Kurikulum 2013 yang dibuat guru SMP Negeri 2 Tanjungpinang tahun 2018 dapat meningkat. Berdasarkan Hasil penelitian yang dilaksanakan, kemampuan guru SMP Negeri 2 Tanjungpinang tahun 2018 dalam menyusun RPP Kurikulum 2013 dapat meningkat melalui penerapan supervisi akademik.

\section{Kesimpulan}

\section{A. Simpulan}

Berdasarkan rumusan masalah, hipotesis dan hasil penelitian, peneliti menyimpulkan bahwa supervisi akademik dapat meningkatkan kemampuan guru dalam menyusun RPP 2013 bagi para guru SMP Negeri 2 Tanjungpinang Tahun 2018. Adapun peningkatan kemampuan guru dalam menyusun RPP 2013 secara terperinci pada kondisi awal rata-rata 67,38, siklus I rata-rata 75,02 meningkat sebesar 7,64, rata-rata siklus II mencapai 81,39 meningkat 6,37. Pada kondisi awal rata-rata hanya 16,67\% guru yang memperoleh nilai rata-rata $\geq 75$, siklus I guru yang memperoleh nilai rata-rata $\geq 75$ naik menjadi $66,67 \%$ meningkat 50\%. Pada Siklus II guru yang memperoleh nilai rata-rata $\geq 75$ naik lagi menjadi 91,67\% meningkat $25 \%$ dari Siklus I.

Hasil yang dicapai guru sudah memenuhi target yaitu 90\% guru telah mampu menyusun RPP Kurikulum 2013 dengan baik. Peningkatan di atas membuktikan keberhasilan peningkatan guru dalam menyusun kualitas RPP Kurikulum 2013 melalui supervisi akademik pada guru SMP Negeri 2 Tanjungpinang Tahun 2018.

\section{B. Saran}

Berdasarkan hasil penelitian, analisis data dan kesimpulan dalam penelitian ini, ada beberapa hal yang perlu disarankan yaitu :

1. Saran Untuk Guru

a. Hendaknya guru membuat RPP Kurikulum 2013 secara rutin dan dilengkapi lembar kerja, penilaian proses, strategi mengajar dan alat peraganya.

b. Apabila ada masalah atau kesulitan segeralah minta bantuan kepada teman guru, kepala sekolah, atau pengawas untuk memecahkannya, sehingga kualitas RPP Kurikulum 2013 bisa lebih optimal.

Tanjak: Jounal of Education and Teaching, Vol. 2, No. 1, 2021 
c. Kemampuan guru dalam menyusun RPP RPP Kurikulum 2013 akan terwujud bila guru ada kemauan untuk aktif dan kreatif.

2. Saran untuk pengawas

a. Pengawas sebaiknya menjalin hubungan yang baik sebagai mitra kerja bukan sebagai atasan dan bawahan (pengawas adalah sahabat guru).

b. Supervisi akademik diprogramkan minimal $3 \mathrm{kali} / \mathrm{semester} \mathrm{sehingga} \mathrm{guru} \mathrm{akan} \mathrm{terbiasa} \mathrm{disupervisi}$ akademik.

3. Saran untuk Dinas Pendidikan Kota Tanjungpinang

a. Perlu dilaksanasakan kegiatan monitoring dan evaluasi secara berkelanjutan terhadap implementasi Kurikulum 2013.

b. Perlu dilaksanakan bimbingan teknis, workshop, dan pembinaan kompetensi guru lainnya secara terstruktur dan berkesinambungan.

\section{Referensi}

Arikunto, S. (2006). Manajemen Penelitian. Jakarta : Rineka Cipta.

Cece, W. (2009). Kemampuan Dasar Guru dalam Proses Belajar Mengajar. Bandung: Remaja Rosdakarya.

Hoetomo. (2005). Kamus Lengkap Bahasa Indonesia, Surabaya: Mitra Pelajar. Joice, Bruce, Weil, Marsha, (2000), Models of Teaching, Allyn \& Bacon: London.

Kartono, K dan Dali, D. (2007). Kamus Psikologi Pendidikan. Bandung: Pionerjaya.

Kemdikbud RI 2013. Pedoman Diklat Guru dalam Rangka Implementasi Kurikulum 2013. Jakarta: T.P.

Kunandar. (2008). Guru Profesional Implementasi KTSP dan Sukses dalam Sertifikasi Guru. Jakarta: Grafindo Persada.

Mulyasa, E. (2013). Menjadi Guru Profesional: Menciptakan Pembelajaran Kreatif dan Menyenangkan. Bandung: Remaja Rosdakarya.

Hamalik, O. (2004). Pendidikan Guru Berdasarkan Pendidikan Kompetensi. Jakarta: Bumi Aksara.

Peraturan Menteri Pendidikan dan Kebudayaan Nomor 81A Tahun 2013 tentang Implementasi Kurikulum.

Peraturan Pemerintah No.32 Tahun 2013 tentang perubahan atas PP No. 19 tahun 2005 tentang Standar Nasional pendidikan (Lembar Negara RI Tahun 2013 No.71, Tambahan Lembar Negara).

Permendikbud No.54 Tahun 2013 tentang Standar Kompetensi Lulusan Pendidikan Dasar dan Menengah.

Permendikbud No.69 Tahun 2013 tentang Kerangka Dasar dan Struktur Kurikulum Sekolah Menengah Pertama.

Pupuh \& Sutikno, S. (2007). Strategi Belajar Mengajar. Bandung: Rafika Aditama.

Purwanto, N. (2008). Administrasi Dan Supervisi Pendidikan. Bandung: Sosdakarya.

Semiawan, C., Dkk. (1992). Pendekatan Ketrampilan Proses. Jakarta: Gramedia Widya Sarana Indonesia.

Undang-undang Republik Indonesia Nomor 20 Tahun 2003 tentang Sistem Pendidikan Nasional.

UU No 20 tahun 2003 tentang Sisten Pendidikan Nasional (lembar Negara RI tahun 2003 No. 78, Tambahan lembar Negara RI No. 4301).

Tanjak: Jounal of Education and Teaching, Vol. 2, No. 1, 2021 